\title{
Behavior during transition differs for cows diagnosed with claw horn lesions in mid lactation
}

\author{
K. L. Proudfoot, D. M. Weary, and M. A. G. von Keyserlingk ${ }^{1}$ \\ Animal Welfare Program, Faculty of Land and Food Systems, University of British Columbia, 2357 Main Mall, Vancouver, \\ British Columbia, V6T 1Z4, Canada
}

\begin{abstract}
Claw horn lesions, including sole hemorrhages and sole ulcers, are a major cause of lameness in dairy cattle. These lesions often develop in the weeks around calving and become visible 8 to 12 wk later. The aim was to determine whether cows that are diagnosed with claw horn lesions several weeks after calving behave differently during the calving period when the lesions are thought to first develop. The claws of 26 multiparous Holstein dairy cows were scored for sole hemorrhage severity and presence of sole ulcers 2 wk before calving, 3 wk after calving, and every 4 wk thereafter until 15 wk after calving. Of the 26 cows, 13 cows had no or low lesion scores up to $15 \mathrm{wk}$ and 13 cows had at least 1 new severe lesion or sole ulcer diagnosed between 7 and 15 wk after calving. Behavior (dry matter intake, feeding time and rate, number and size of meals, standing time, number and duration of standing bouts, location of standing, and displacements at the feed bunk) was recorded from $2 \mathrm{wk}$ before calving to $3 \mathrm{wk}$ after calving. Behavior during the 2 wk before calving, first 24 $\mathrm{h}$ after calving, $1 \mathrm{wk}$ after calving, and 2 to 3 wk after calving was compared between cows with and without lesions in mid lactation. Multivariate regression was used to determine the predictive value of each behavior and combination of behaviors on lesion diagnosis. Cows diagnosed with lesions in mid lactation spent more time standing than cows without lesions during the 2 wk before $(832 \pm 29$ vs. $711 \pm 29 \mathrm{~min} / \mathrm{d})$ and $24 \mathrm{~h}$ after $(935 \pm 46$ vs. $693 \pm 46 \mathrm{~min} / \mathrm{d})$ calving. These differences were driven by an increase in the time spent perching with front feet in the stall $(241 \pm 22$ vs. 147 $\pm 22 \mathrm{~min} / \mathrm{d}$ at $2 \mathrm{wk}$ before calving) and an increase in standing bout duration (101 \pm 10 vs. $56 \pm 10 \mathrm{~min} /$ bout at $24 \mathrm{~h}$ after calving). Compared with cows without lesions, cows with lesions consumed feed at a faster rate ( $86 \pm 3$ vs. $77 \pm 3 \mathrm{~g} / \mathrm{min})$ during the 2 wk before calving and consumed more feed $(17.9 \pm 0.9$ vs. $12.3 \pm$
\end{abstract}

Received September 24, 2009.

Accepted May 25, 2010.

${ }^{1}$ Corresponding author: nina@interchange.ubc.ca
$0.9 \mathrm{~kg} / \mathrm{d}$ ) during the $24 \mathrm{~h}$ after calving. The number of displacements at the feeder was not different between groups. These results indicate that a combination of feeding and standing behavior during the transition can serve as early indicators of claw horn lesions in mid lactation.

Key words: lameness, sole hemorrhage, standing behavior, feeding behavior

\section{INTRODUCTION}

Lameness in dairy cattle is a major source of economic loss for producers and compromised welfare for affected cows. Common hoof ailments associated with lameness include sole hemorrhages, white line hemorrhages, and sole ulcers (i.e., claw horn lesions; Bicalho et al., 2009).

These claw horn lesions often develop around calving and typically become visible 8 to 12 wk later (Chapinal et al., 2009). The transition period from 3 wk before to 3 wh after calving is considered a trigger factor for claw horn lesions that arise several weeks later (Cook and Nordlund, 2009). Physiological changes during transition that predispose cows to claw horn lesions include weakening of the connective tissue of the hoof suspensory apparatus (Tarlton et al., 2002) and a decrease in the thickness of the digital cushion (Bicalho et al., 2009), both of which can impair the resilience of the feet to external stresses. The development of claw horn lesions during transition is likely multifactorial; physiological changes can be compounded by environmental risks for lesions, such as a hard standing surface (Greenough and Vermunt, 1991; Webster, 2002).

Cow behavior during transition may additionally contribute to the development of claw horn lesions. In stages of lactation outside of the transition period, the amount of time cows spend standing (Chapinal et al., 2009), their social status within the pen (Galindo and Broom, 2000), and their feeding behavior (Nocek, 1997) were different for lame and nonlame animals. These behaviors thought to contribute to the development of lameness (i.e., feeding, standing, and social behavior) are often linked. Thus, a combination of behaviors 
during transition may exacerbate environmental and physiological risk factors for lameness present during transition. Chapinal et al. (2009) found that cows diagnosed with ulcers in mid lactation had a greater increase in standing time during transition compared with cows that remained healthy, but reasons for this increase in standing time were not assessed. Proudfoot et al. (2009) speculated that social factors such as competition at the feed bunk can influence standing time during transition; cows that were forced to compete for feed spent more time standing than cows that did not have to compete. Social behavior can affect feeding behavior (i.e., feed intake, time spent feeding, and rate of feed intake), which likely leads to variation in intake among cows, potentially causing acidosis in some animals, thus increasing the risk of claw horn lesions (Nocek, 1997; Cook et al., 2004).

The objective was to determine whether cows that are diagnosed with sole hemorrhages or sole ulcers in mid lactation differ in their standing, social, and feeding behavior during the transition period from those cows that do not develop lesions. A second objective was to determine which behaviors during transition would best predict which cows would later be diagnosed with these claw horn lesions.

\section{MATERIALS AND METHODS}

\section{Animals, Housing, and Diet}

This study was conducted at the University of British Columbia's Dairy Education and Research Centre (Agassiz, British Columbia, Canada). All animals were cared for according to the guidelines of the Canadian Council on Animal Care (1993). A total of 55 multiparous Holstein dairy cows (parity $=2.9 \pm 1.1$, mean \pm SD) was monitored over a 9-mo period. Animals were housed in 1 precalving pen and 1 postcalving pen, each containing 20 freestalls fitted with mattresses (Pasture Mat, Promat Inc., Woodstock, Ontario, Canada) covered with $5 \mathrm{~cm}$ of sand bedding. Pens had vulcanized rubber floors in the alleys and crossovers (Red Barn Dairy Mat, North West Rubber Mats Ltd., Abbotsford, British Columbia, Canada) and an electronic feeding system that included 12 feed bins (Insentec, Marknesse, Holland; Chapinal et al., 2007). All cows could access all feed bins, but only a single cow could access a single bin at any given time. The feed bin recorded the time of day, duration, and intake during each visit. Stocking density was maintained at 20 cows per pen (i.e., 20 cows, 12 feed bins).

Cows entered the precalving pen $25 \pm 2$ d before their expected calving date and were moved to the maternity pen when they showed physical signs of im-
Table 1. Ingredient and chemical composition of the pre- and postcalving TMR

\begin{tabular}{|c|c|c|}
\hline Composition & Precalving & Postcalving \\
\hline \multicolumn{3}{|l|}{ Ingredient (\% DM) } \\
\hline Corn silage & 21.3 & 14.7 \\
\hline Grass silage & - & 21.3 \\
\hline Alfalfa hay & 42.8 & 12.3 \\
\hline Concentrate $^{1}$ & 35.9 & 51.7 \\
\hline \multicolumn{3}{|c|}{ Chemical composition } \\
\hline DM $(\%)$ & 50.8 & 51.1 \\
\hline $\mathrm{CP}(\%$ of $\mathrm{DM})$ & 14.4 & 17.7 \\
\hline $\mathrm{ADF}(\%$ of $\mathrm{DM})$ & 35.0 & 23.7 \\
\hline $\mathrm{NDF}(\%$ of $\mathrm{DM})$ & 45.6 & 36.1 \\
\hline $\mathrm{NE}_{\mathrm{L}}(\mathrm{Mcal} / \mathrm{kg})$ & 1.40 & 1.66 \\
\hline
\end{tabular}

${ }^{1}$ Contained $60.0 \%$ ground beet pulp, $10.0 \%$ rye distillers, $8.0 \%$ canola meal, 7.0\% Amipro (Unifeed Ltd., Chilliwack, British Columbia, Canada), $6.0 \%$ flattened barley, $2.95 \%$ dairy trace mineral-vitamin premix, $1.33 \%$ vitamin $\mathrm{E}, 1.0 \%$ dicalcium phosphate, $0.88 \%$ niacin, $0.75 \%$ magnesium oxide, $0.6 \%$ iodized salt, $0.59 \%$ limestone, $0.5 \%$ calcium sulfate, $0.4 \%$ cane molasses.

minent calving (i.e., udder enlargement, milk let-down, and relaxation of sacrosciatic ligament). The maternity pen contained a sand-bedded pack with 6 Insentec feed bins and 1 Insentec water trough. There was a maximum of 2 cows in this pen at any given time. Cows were moved to a postcalving pen within $24 \mathrm{~h}$ after calving, where they remained for $21 \mathrm{~d}$. Cows in the postcalving pen were milked twice daily at approximately 0700 and $1700 \mathrm{~h}$. Only behavioral data collected from the $2 \mathrm{wk}$ before calving to $3 \mathrm{wk}$ after calving were included in the analysis. For the remainder of the trial (i.e., 15 wk), cows were housed in 1 of 2 pens with vulcanized rubber floors in the alley adjacent to the feed bunk. The flooring in the remaining alleys and crossovers was grooved concrete.

For all pens, fresh feed was provided twice daily at approximately 0800 and $1600 \mathrm{~h}$. Three samples of preand postcalving TMR were taken per week and pooled before analysis. Samples were dried at $60^{\circ} \mathrm{C}$ for $2 \mathrm{~d}$ to determine DM. Dried weekly samples were pooled into monthly samples and sent for nutrient analysis (Cumberland Valley Analytical Services Inc., Maugansville, $\mathrm{MD})$ to determine the average $( \pm \mathrm{SD}) \mathrm{CP}, \mathrm{ADF}, \mathrm{NDF}$, total digestible nutrient, and $\mathrm{NE}_{\mathrm{L}}$ content of the feed (Table 1).

\section{Feeding Behavior}

The time of calving for each cow was determined from video recordings. Two cameras (CCTV camera, model WV-BP330, Panasonic, Osaka, Japan) were mounted directly above the lying stalls of the precalving and maternity pens. Cameras were connected to a video multiplexer (Panasonic Video Multiplexer, WJ FS 416) and a time-lapse videocassette recorder (Panasonic 
Time-Lapse VCR, AG-6540). For all behaviors, the day after calving $(24 \mathrm{~h})$ was adjusted so that the first hour of this period was the hour of calving. All other days ( 2 wk before to 3 wk after calving) were recorded from midnight to midnight.

Data collected from the feed bins were used to determine the time of day, duration, and the amount of feed consumed at each visit to the bin. Dry matter intakes were calculated by correcting weekly intakes for DM content. Feeding rate was calculated as the ratio of DMI to time spent feeding during each visit to the feed bins; these feeding rates were averaged over $1 \mathrm{~d}$ to create 1 value per cow per day.

The number of meals consumed per day was computed by first establishing a meal criterion. A meal criterion was the minimum time away from the feeder such that the next visit was considered a new meal; this criterion was identified using discontinuities in the distribution of intervals using the mixed distribution method described by Tolkamp and Kyriazakis (1999). Based on our data, pooled meal criteria of $16.7 \mathrm{~min}$ for the $2 \mathrm{wk}$ before calving and $20.1 \mathrm{~min}$ for the $3 \mathrm{wk}$ after calving were used to calculate the number of meals and the size of each meal.

\section{Standing Behavior}

Standing behavior was collected using modified data loggers (Gemini Dataloggers Ltd., Chichester, UK) validated by O'Driscoll et al. (2008). Data loggers were modified with a mercury switch that recorded leg orientation (horizontal or vertical) at 1-min intervals. These data were used to calculate daily standing time as well as the frequency of transitions from standing to lying positions (i.e., standing bouts). A standing bout began when a cow stood up and ended when the cow returned to lying. The average duration of standing bouts per day was calculated as a ratio of minutes standing to the number of standing bouts per day. Data loggers were attached to the hind leg of cows upon entry into the precalving pen and were removed $21 \mathrm{~d}$ after calving; data were offloaded weekly when cows were in the milking parlor.

The location of standing was recorded from video using 10-min scan sampling during $4 \mathrm{~d}$ in the $2 \mathrm{wk}$ before calving. Scan sampling was validated as a reliable measure of daily standing behavior (validated for cattle by Mitlöhner et al., 2001). Standing locations included standing while feeding, standing in the feed alley (not feeding), standing in the alley adjacent to the lying stalls, standing with 2 front feet in the stall (i.e., perching), and standing with 4 feet in the stall.

\section{Social Behavior}

Displacements at the feed bins were recorded using video from 2 cameras mounted $6 \mathrm{~m}$ above the feed bins in each of the precalving pens. Displacements were recorded for 90 min following the twice-daily delivery of fresh feed for the same $4 \mathrm{~d}$ used to measure standing location 2 wk before calving. Data collected from the morning and afternoon feedings were summed to create 1 value per cow per day; these values were averaged to create 1 value per cow.

A displacement was recorded when a butt or a push from the "actor" resulted in the complete withdrawal of another cow's head (the "reactor") from the feed bin. An index of displacements was created, as described by Galindo and Broom (2000), calculating the proportion of displacements a cow instigated relative to her overall displacements in the group. This index was used to categorize animals as low ranking (index $<0.4$ ), middle ranking (index $>0.4$ and $<0.6$ ), or high ranking (index $>0.6)$.

\section{Clinical Examination of Hooves}

Hooves were examined approximately 2 wk precalving, 3 wk postcalving, and at monthly intervals thereafter (i.e., wk 7, 11, and 15). At each examination, hooves were pared by a trained hoof trimmer to reveal a clean horn surface. The presence of claw horn lesions (sole hemorrhages, sole ulcers, white line hemorrhages), digital dermatitis, and interdigital hyperplasia were recorded for front and rear hooves using a foot map that divided each claw into 6 zones based on Greenough and Vermunt (1991). Claw horn lesions were scored for location and severity by a trained observer using a validated 6-point scoring system modified from Leach et al. (1998): 1 = diffuse yellow discoloration, $2=$ diffuse red discoloration, $3=$ deep, dense red lesion, $4=$ portcolored lesion, $5=$ red color, raw and bleeding lesion, and $6=$ ulcer, corium exposed.

\section{Cow Participation}

Cows were retrospectively assigned to a lesion category based on the most severe lesion on the sole (i.e., zone 4 or 5) diagnosed between wk 7 and 15 after calving. As a result of the association between disease and feeding behavior during the transition period (Huzzey et al., 2007; Goldhawk et al., 2009), animals diagnosed with any clinical diseases, including ketosis, retained placenta, or metritis, were excluded from the study (n $=13$ ). Moreover, standing behavior was directly af- 
fected by lameness (Chapinal et al., 2009); thus, cows diagnosed with a sole ulcer or interdigital hyperplasia during transition were removed from the final data set $(\mathrm{n}=6)$. Ten cows that were diagnosed with a moderate lesion between wk 7 and 15 were removed from the analysis. Together this resulted in the exclusion of 29 cows. Of the remaining 26 cows, 13 had no visible lesions, 5 had sole ulcers, and 8 had severe sole hemorrhages with a score of 4 or 5 (Leach et al., 1998).

\section{Statistical Analyses}

Cow was considered the experimental unit $(\mathrm{n}=26)$. The GLM procedure in SAS (version 9.1; SAS Institute, 2003) was used to determine whether cows that were diagnosed with severe sole hemorrhages differed from cows that were diagnosed with sole ulcers; there were no differences for any behaviors except in the number and duration of standing bouts during the 2 wk before calving. Based on this result, cows were grouped with severe sole hemorrhages and sole ulcers together as having lesions. These 13 lesion cows were compared with the 13 cows with no lesions.

To detect differences in feeding and standing behavior during transition between cows with and without lesions in mid lactation, data were summarized into the following periods: 2 wk before calving ( $\mathrm{d}-14$ to -1 , referred to as wk -2 ), the first $24 \mathrm{~h}$ after calving (referred to as $24 \mathrm{~h}$ ), the first wk after calving (d 2 to 7 , referred to as wk 1), and the 2 to 3 wk after calving (d 8 to 21, referred to as wk 2). Periods were tested separately because there were different predictions for each period.

The GLM procedure in SAS was used to detect differences in daily DMI, feeding time, feeding rate, number and duration of meals, standing time, number of standing bouts, and average duration of standing bouts for each period. The model for each variable included parity as a covariate and lesion category (lesion or no lesion) as a fixed effect. The LSMEANS statement was used to calculate least squares means and standard errors. Differences between groups in the location of standing were tested using the same model during just the $2 \mathrm{wk}$ before calving.

It was clear from the above analysis that there were differences in feeding and standing behavior in the week before calving. To detect any diurnal differences in behavior during this precalving period, DMI, feeding rate, and standing time data were summarized into hourly periods. The GLM procedure in SAS was used to assess differences in diurnal patterns between cows that were diagnosed with lesions later in lactation and those without lesions. The model included parity as a covariate, hour as a repeated measure, lesion category (lesion or no lesion), and a lesion category by hour interaction. Autoregressive covariance structure was used for the model as determined by best fit.

Differences between cows with and without lesions in the total number of displacements each cow was engaged in and her displacement index during wk -2 before calving were analyzed using the GLM procedure in SAS. The model included parity as a covariate and lesion category (lesion or no lesion) as a fixed effect. Differences in the proportion of cows that became lame across the 3 displacement index categories (Galindo and Broom, 2000) were tested using a Fisher's exact test.

Multivariate logistic regression (LOGISTIC procedure of SAS) was used to determine the predictive value of the variables that were significantly different between treatments as well as a combination of these variables. Univariate logistic models were first used to fit 1 variable at a time. Correlation between variables was assessed (CORR procedure of SAS) to avoid including highly related variables in the same model. Receiver operating characteristics curves were plotted and the area under the curve (AUC) was used to compare the accuracy of the different models in discriminating cows that were diagnosed with lesions from those that were not. Multivariate models were constructed using a forward stepwise procedure based on a selection criterion of $P<0.10$. Differences between groups in production measurements (milk production, BW, and parity) were tested using the GLM procedure.

\section{RESULTS}

\section{Production}

No differences were found between groups in BW before calving (no lesion vs. lesion: $742 \pm 16$ vs. 717 $\pm 15.3 \mathrm{~kg} ; P=0.27$ ), BW after calving (no lesion vs. lesion: $694 \pm 14$ vs. $679 \pm 14 \mathrm{~kg} ; P=0.45), 21$-d milk production (no lesion vs. lesion: 41.9 vs. $42.9 \mathrm{~kg} / \mathrm{d} ; P=$ 0.67 ), or parity (no lesion vs. lesion: parities $2.8 \pm 0.3$ vs. $3.0 \pm 0.3 ; P=0.62)$.

\section{Standing Behavior}

Cows diagnosed with lesions in mid lactation stood for approximately $2 \mathrm{~h}$ (121 min) longer per day during the 2 wk before calving than cows without lesions $(832$ \pm 29 vs. $711 \pm 29 \mathrm{~min} / \mathrm{d} ; P=0.007)$. A difference was also found for the $24 \mathrm{~h}$ after calving (935 \pm 49 vs. 693 $\pm 48 \mathrm{~min} / \mathrm{d} ; P=0.001)$, but not in wk 1 or 2 after calving (Figure 1). The frequency of standing bouts during the $24 \mathrm{~h}$ after calving was lower for cows that were diagnosed with lesions $(10.6 \pm 0.9$ vs. $13.4 \pm 0.9$ standing bouts $/ \mathrm{d} ; P=0.04)$, and the duration of each 

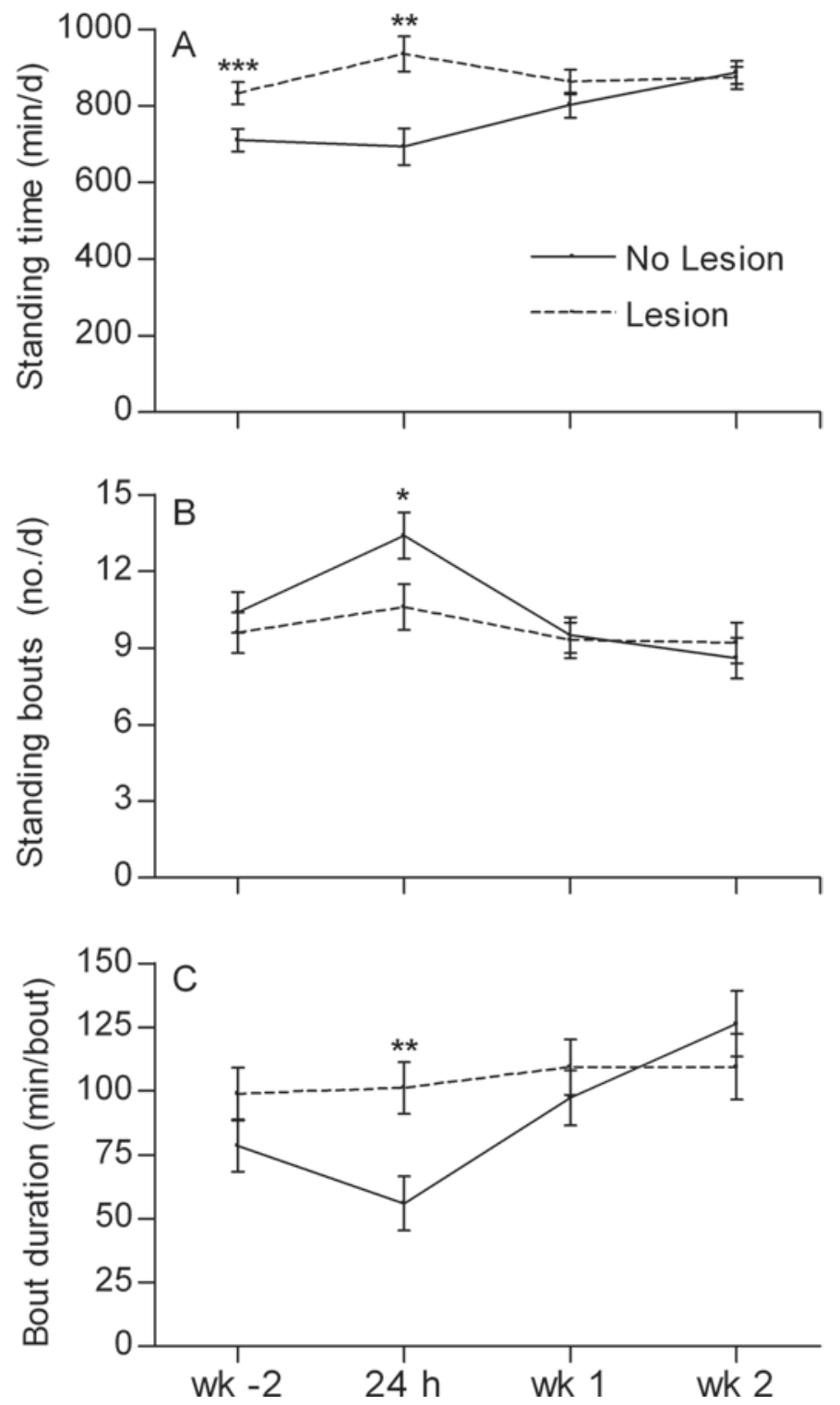

Figure 1. Daily standing time (A), number of standing bouts (B), and standing bout duration (C) of cows that were diagnosed with severe sole hemorrhages and sole ulcers $(\mathrm{n}=13)$ and those without lesions $(\mathrm{n}=13)$ from 2 wk before to 3 wk after calving. Least squares means \pm SE. ${ }^{*} P \leq 0.05 ;{ }^{* *} P \leq 0.01 ;{ }^{* * *} P \leq 0.001$.

standing bout was longer for these cows $(101 \pm 10$ vs. $56 \pm 11 \mathrm{~min} /$ standing bout; $P=0.005$ ). No differences in standing bouts or bout duration were found for any other period.

Figure 2 shows the time per day that cows in each group stood in different locations of the pen. Perching time during the $2 \mathrm{wk}$ before calving averaged $94 \mathrm{~min} / \mathrm{d}$ higher for cows that were diagnosed with lesions than for cows without lesions $(241 \pm 22$ vs. $147 \pm 22 \mathrm{~min} / \mathrm{d}$; $P=0.007)$. There was a tendency for cows that were diagnosed with lesions to stand longer in the feed alley

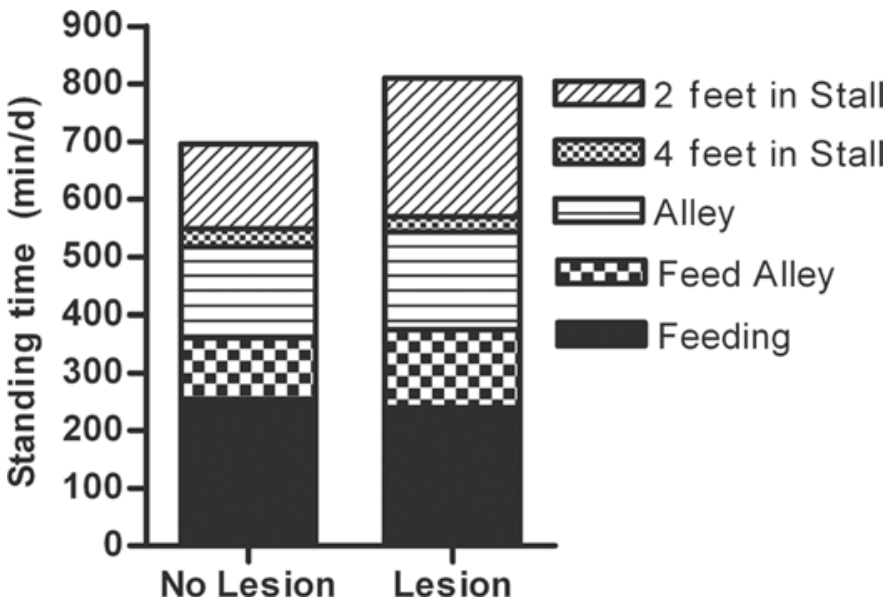

Figure 2. Standing location of cows that were diagnosed with severe sole hemorrhages and sole ulcers $(\mathrm{n}=13)$ and those without lesions $(\mathrm{n}=13)$ during the $2 \mathrm{wk}$ before calving. Locations included standing while feeding (feeding), standing in the feed alley and not feeding (feed alley), standing in the alley adjacent to the lying stalls (alley), standing with 4 feet in the stall, and standing with 2 front feet in the stall.

(not feeding) compared with cows without lesions (135 \pm 10 vs. $106 \pm 10 \mathrm{~min} / \mathrm{d} ; P=0.06)$.

\section{Feeding Behavior}

Cows that were diagnosed with lesions in mid lactation ate at a faster rate $(P=0.05)$ and had more frequent $(P=0.02)$ but slightly smaller meals $(P=$ $0.10)$ during the 2 wk before calving compared with cows that did not develop lesions (Table 2). In the $24 \mathrm{~h}$ after calving, cows with lesions consumed more feed $(P$ $>0.001)$ in more frequent meals $(P=0.05)$ and tended to eat at a faster rate $(P=0.09)$ than did cows without lesions. During wk 1, cows with lesions continued to consume more feed $(P=0.01)$ in larger $(P=0.01)$, rather than more frequent, meals compared with cows without lesions. By wk 2 after caving, there were no detectable differences in feeding behavior.

\section{Diurnal Pattern}

There was no difference in the diurnal pattern of DMI during the 2 wk before calving between cows with and without lesions $(P=0.79$; Figure 3$)$. There was an hour by lesion category interaction for feeding rate and standing time (feeding rate: $P=0.002$; standing time: $P=0.001)$ whereby cows diagnosed with lesions spent more time standing in the early morning and between peak feeding times and ate faster at peak feeding times compared with cows without lesions. 
Table 2. Least squares means \pm SEM of feeding behavior of cows that were diagnosed with severe sole hemorrhages and sole ulcers $(\mathrm{n}=13)$ and those without lesions $(\mathrm{n}=13)$ from 2 wk before to 3 wk after calving

\begin{tabular}{|c|c|c|c|c|}
\hline Item & No Lesion & Lesion & SEM & $P$-value \\
\hline \multicolumn{5}{|c|}{ DMI $(\mathrm{kg} / \mathrm{d})$} \\
\hline wk -2 & 16.8 & 17.0 & 0.6 & 0.82 \\
\hline $24 \mathrm{~h}$ & 12.3 & 17.9 & 0.9 & $>0.001$ \\
\hline wk 1 & 15.8 & 18.5 & 0.6 & 0.01 \\
\hline wk 2 & 19.8 & 21.3 & 0.7 & 0.15 \\
\hline \multicolumn{5}{|c|}{ Feeding time $(\min / \mathrm{d})$} \\
\hline wk -2 & 228 & 213 & 9 & 0.26 \\
\hline $24 \mathrm{~h}$ & 110 & 139 & 12 & 0.11 \\
\hline wk 1 & 158 & 172 & 8 & 0.20 \\
\hline wk 2 & 208 & 212 & 11 & 0.84 \\
\hline \multicolumn{5}{|c|}{ Feeding rate $(\mathrm{g} / \mathrm{min})$} \\
\hline wk -2 & 77 & 86 & 3 & 0.05 \\
\hline $24 \mathrm{~h}$ & 121 & 137 & 7 & 0.09 \\
\hline wk 1 & 106 & 113 & 4 & 0.29 \\
\hline wk 2 & 102 & 107 & 5 & 0.50 \\
\hline \multicolumn{5}{|c|}{ Meals (no/d) } \\
\hline wk -2 & 6.3 & 7.1 & 0.2 & 0.02 \\
\hline $24 \mathrm{~h}$ & 6.0 & 7.6 & 0.5 & 0.05 \\
\hline wk 1 & 8.1 & 7.8 & 0.3 & 0.60 \\
\hline wk 2 & 7.4 & 7.2 & 0.2 & 0.60 \\
\hline \multicolumn{5}{|c|}{ Meal size $(\mathrm{kg} /$ meal $)$} \\
\hline wk -2 & 2.8 & 2.5 & 0.1 & 0.10 \\
\hline $24 \mathrm{~h}$ & 2.2 & 2.5 & 0.4 & 0.42 \\
\hline wk 1 & 2.1 & 2.6 & 0.1 & 0.01 \\
\hline wk 2 & 2.8 & 3.0 & 0.1 & 0.10 \\
\hline
\end{tabular}

\section{Social Behavior}

No differences were found during the 2 wk before calving between cows that were diagnosed with lesions and cows without lesions in the total number of displacements at the feed bins or in the average displacement index. When cows were categorized as low, middle, and high ranking, a difference was detected in the proportion of cows with and without lesions that fell into each category $(P=0.02)$. Cows without lesions were more likely middle ranking (displacement index $>0.40$ and $<0.60)$ than cows with lesions. Of the 13 cows with lesions after calving, 10 were middle ranking, 1 was low ranking $(<0.40)$, and 2 were high ranking $(>0.60)$. In contrast, 3 cows that were diagnosed with lesions after calving were middle ranking, 4 were low ranking, and 6 were high ranking (Figure 4).

\section{Logistic Regression}

Table 3 shows the odds ratio with $95 \%$ confidence intervals, AUC, coefficient of determination, and Wald $P$-value of the following variables: wk -2 standing time, perching time, feeding rate and meals, 24 -h standing time, DMI, standing bout duration and meals, and wk 1 DMI. Standing time during wk -2 was correlated with perching time $(\mathrm{r}=0.75)$ and $24-\mathrm{h}$ standing time $(\mathrm{r}=$ $0.64), 24$-h standing time was correlated with standing bout duration $(\mathrm{r}=0.69)$, and 24-h DMI was correlated with wk 1 DMI $(\mathrm{r}=0.54)$; these correlated variables were not combined in the same multivariate model. Moreover, meal variables were highly correlated with intake, so these variables were not included in complete logistic models. The variable with the highest AUC was 24-h DMI (0.86). The AUC increased from 0.86 to 0.87 after adding the wk -2 daily standing time (likelihood ratio $P=0.0007$ ) and to 0.91 after adding the wk -2 feeding rate (likelihood ratio $P=0.0007$ ). When wk -2 perching time was substituted for standing time, the AUC of the model was 0.95 (likelihood ratio $P=$ 0.0003). When wk 1 DMI was substituted for 24-h DMI (wk 1 DMI, wk -2 standing time, and wk -2 feeding rate), the $\mathrm{AUC}$ was 0.91 (likelihood ratio $P=0.0009$ ), and when wk -2 perching time was substituted for standing time in this model, the AUC was 0.90 (likelihood ratio $P=0.008)$.

\section{DISCUSSION}

Our results provide the first evidence that lesions diagnosed 7 to 15 wk after calving are associated with changes in behavior during the transition period. What remains unclear is whether these behavioral differences contribute to the development of the lesions or are a consequence of an existing ailment. Regardless, these differences in behavior at transition can serve as early indicators of lesions that can be diagnosed only much later in lactation. 
Cows that were diagnosed with lesions stood for longer than cows without lesions during the 2 wk before calving. Our results support those of Chapinal et al. (2009) in that cows diagnosed with sole ulcers in mid lactation began to increase their standing time during the 2 wk before calving. High standing times during transition likely increase the risk for lesions; there is evidence that prolonged standing on a hard surface can increase pressure on the third phalanx, thereby com-
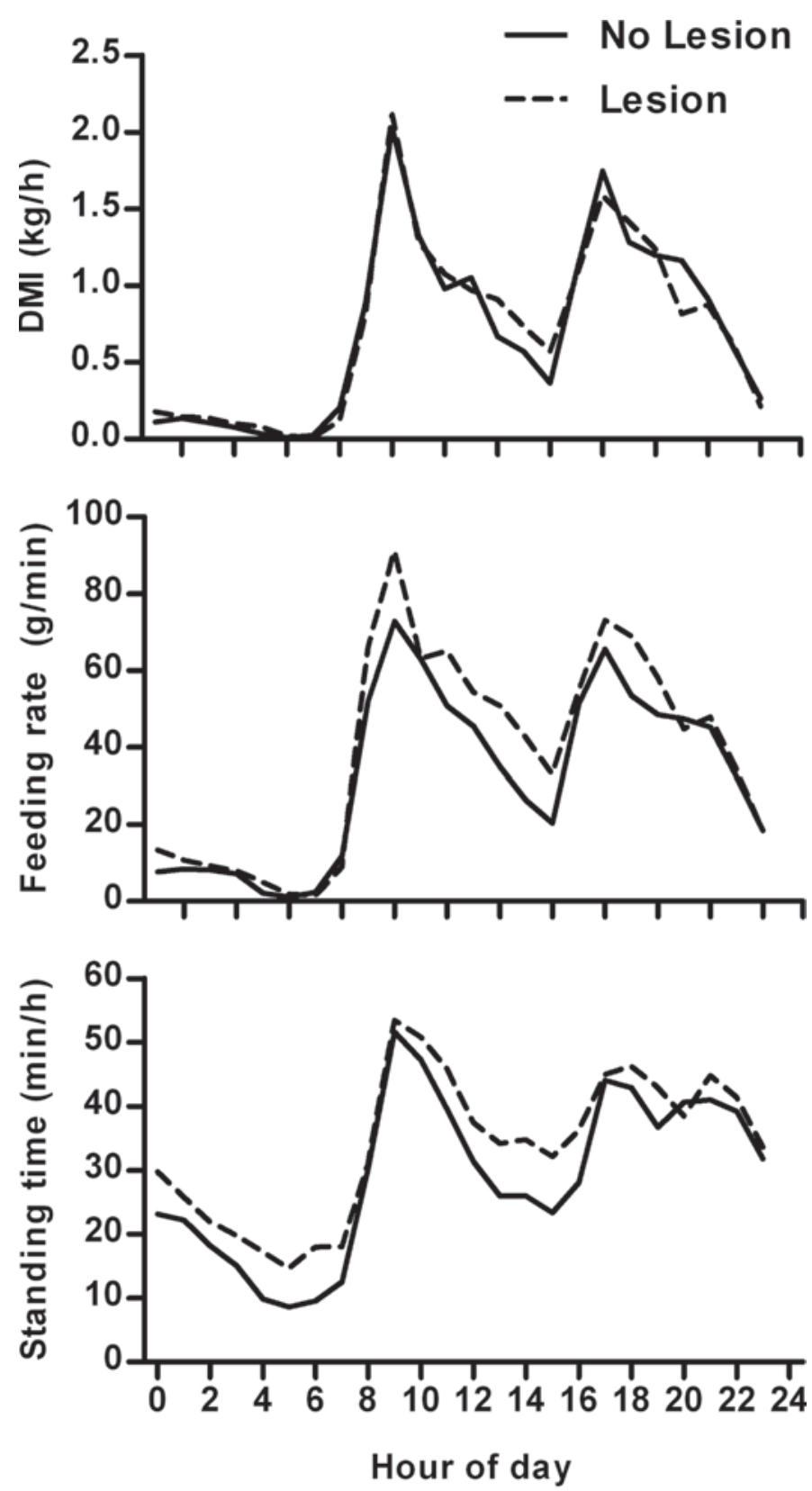

Figure 3. Diurnal pattern of DMI (A), feeding rate (B), and standing time $(\mathrm{C})$ of cows that were diagnosed with severe sole hemorrhages and sole ulcers $(\mathrm{n}=13)$ and those without lesions $(\mathrm{n}=13)$ during the 2 wk before calving. Least squares means \pm SE. pressing the horn-producing tissue in the corium and compounding parturition-related changes in the hoof (Lischer et al., 2002).

A higher daily standing time during the weeks before calving for cows that develop lesion in mid lactation was driven by an increase in time spent perching with 2 front feet in the stall. The literature on perching has considered the behavior both a cause and an effect of lameness (Leonard et al., 1994; Galindo et al., 2000). An increase in this behavior could be driven by the design of the lying stall; cows spent less time perching when the stalls were designed to allow cows to stand fully inside the stall (e.g., by widening the stall or moving the neck rail further from the rear curb; Tucker et al., 2004; Fregonesi et al., 2009).

Cows diagnosed with lesions in mid lactation consumed more feed in more frequent meals during the $24 \mathrm{~h}$ and $1 \mathrm{wk}$ after calving. Previous work has shown that lame cows reduce DMI in the days before diagnosis (González et al., 2008) as a result of pain associated with the condition. Variation in feed intake in early lactation is not likely a consequence of the developing lesions, but instead a response to the introduction of a higher concentrate diet and a new social group. The current data do not allow us to determine whether the increased intake contributed to acidosis-related changes in the hoof, but cows with a high intake after calving may have an exaggerated decrease in rumen $\mathrm{pH}$ (Fairfield et al., 2007). Future work is encouraged to identify the possible mechanisms by which the development of lesions may be affected by feed consumption immediately after calving.

Cows diagnosed with a lesion in mid lactation consumed feed more rapidly during the 2 wk before calving, and this difference was most evident at peak feeding time. A high rate of feed intake was associated with more extensive sorting of the feed for small particles (Devries et al., 2007) as well as greater social pressure at the feed bunk (Nielsen, 1999; Proudfoot et al., 2009). There is likely a combination of factors influencing feeding rate in transition cows, and research addressing the causes and consequences of increased feeding rate during transition is encouraged.

The displacement index is used as an indicator of social rank; it reflects how often a cow displaces another cow versus being displaced. Cows diagnosed with a lesion in mid lactation were more likely to be either high or low ranking compared with cows without lesions that were primarily categorized as middle ranking. High social rank has been associated with older age, a factor that was associated with lameness (Espejo et al., 2006); however, with a small sample of cows in each age group we were unable to provide a powerful test of age effects. Low social rank was associated with 


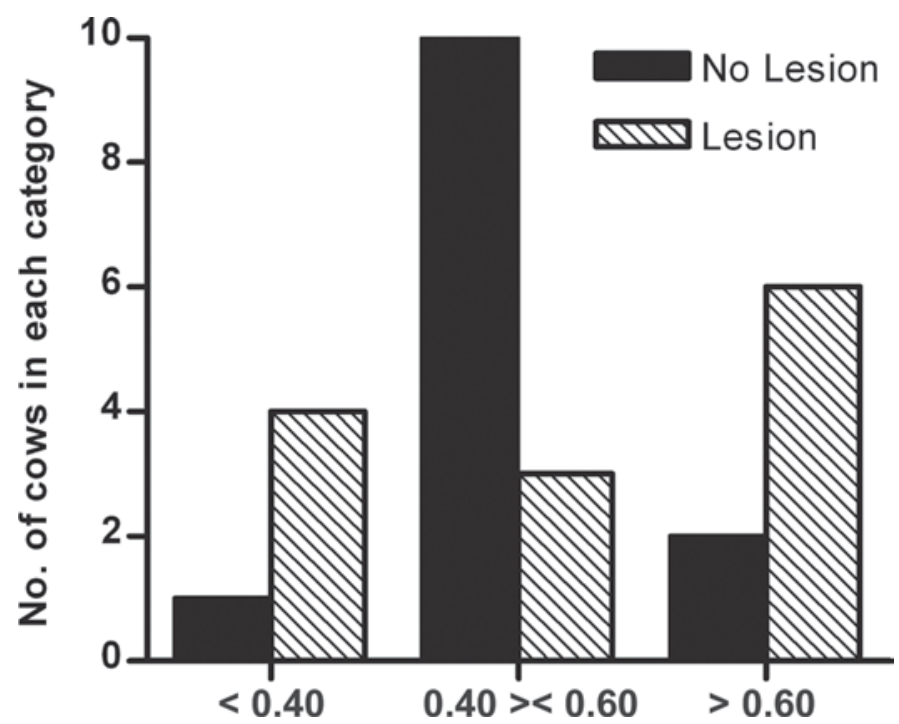

Figure 4. Number of cows with and without severe sole hemorrhages and sole ulcers $(\mathrm{n}=13$ per group) in the low- (displacement index $<0.4)$, middle- $(>0.4$ and $<0.6)$, and high-ranking $(>0.6)$ categories. This index is calculated as a ratio of the number of displacement instigations to the total number of displacements (following Galindo and Broom, 2000) during the 2 wk before calving.

lameness (Galindo et al., 2000) and increased standing time (Galindo and Broom, 2000), and thus may increase the risk of lesions by increasing potential hoof trauma caused by the displacements.

Implications of this study follow the suggestions of Knott et al. (2007) and Cook and Nordlund (2009): good husbandry during the transition period helps curb lameness in mid lactation. Results from the multivariate analysis suggest that a combination of behaviors, particularly standing time before calving and consuming a large amount of feed the day after calving, can be used to predict which cows may develop lesions later in lactation. The results of Webster (2002) suggested that providing a comfortable standing surface during transition can mitigate external influences on the hoof; results provided here show that transition cow behavior, rather than the environment alone, can contribute to sole hemorrhages and sole ulcers diagnosed in mid lactation. Further research is encouraged to determine whether transition management practices aimed to limit excess standing and perching time (i.e., by providing a comfortable lying or standing surface) and better regulation of DMI directly after calving can reduce the incidence of claw horn lesions in the weeks after calving.

\section{CONCLUSIONS}

Compared with cows without lesions, cows diagnosed with lesions in mid lactation spent more time standing, particularly perching with their 2 front feet in the lying stall, during the 2 wk before calving. Cows that were diagnosed with lesions ate faster than cows without lesions during the 2 wk before calving and consumed more feed in more frequent meals during the $24 \mathrm{~h}$ after calving. Transition cow behavior can serve as an early indicator of sole hemorrhages and sole ulcers that become visible several weeks after calving.

\section{ACKNOWLEDGMENTS}

We thank the staff and students of the University of British Columbia's Dairy Education and Research Centre (Agassiz, British Columbia, Canada), including Barry Thompson for hoof trimming and Doug Veira and Julie Huzzey for their help running the experiment. We thank Sarah Barrett for her assistance with the data collection and Núria Chapinal for her help with statistics. This research was funded in part by Westgen Endowment Fund (Milner, British Columbia, Canada) and Investment Agriculture Foundation of British Columbia (Victoria, British Columbia, Canada), as well as

Table 3. Results of logistic regression for a cow diagnosed with a lesion (i.e., severe sole hemorrhage or sole ulcer; $\mathrm{n}=13)$ or not $(\mathrm{n}=13)$ using measures of feeding and standing behaviors as predictors ${ }^{1}$

\begin{tabular}{|c|c|c|c|c|c|}
\hline Item & OR & $95 \% \mathrm{CI}$ & AUC & $\mathrm{R}^{2}$ & $P_{\text {Wald }}$ \\
\hline wk -2 standing time ${ }^{2}$ & 1.48 & $1.06-2.06$ & 0.81 & 0.27 & 0.02 \\
\hline wk -2 perching time ${ }^{3}$ & 1.14 & $1.02-1.28$ & 0.81 & 0.24 & 0.02 \\
\hline wk -2 feeding rate & 1.11 & $0.99-1.24$ & 0.71 & 0.18 & 0.07 \\
\hline wk -2 meals & 3.17 & $1.03-9.74$ & 0.73 & 0.18 & 0.04 \\
\hline $24 \mathrm{~h}$ standing time ${ }^{2}$ & 1.25 & $1.03-1.52$ & 0.78 & 0.30 & 0.02 \\
\hline 24 h DMI & 1.51 & $1.12-2.04$ & 0.86 & 0.37 & 0.007 \\
\hline $24 \mathrm{~h}$ bout duration ${ }^{3}$ & 1.50 & $1.05-2.14$ & 0.78 & 0.30 & 0.02 \\
\hline $24 \mathrm{~h}$ meals & 1.56 & $0.98-2.56$ & 0.73 & 0.16 & 0.06 \\
\hline wk 1 DMI & 1.62 & $1.07-2.46$ & 0.78 & 0.24 & 0.02 \\
\hline
\end{tabular}

${ }^{1} \mathrm{OR}=$ odds ratio; $\mathrm{AUC}=$ area under the receiver operating characteristics curve.

${ }^{2} \mathrm{OR}$ adjusted to a 30 -min increase.

${ }^{3} \mathrm{OR}$ adjusted to a 10 -min increase. 
Canada's Natural Sciences and Engineering Research Council Industrial Research Chair Program (Ottawa, Ontario, Canada) with contributions from Dairy Farmers of Canada (Ottawa, Ontario, Canada) and many other listed on the Animal Welfare Web site at http:// www.landfood.ubc.ca/animalwelfare.

\section{REFERENCES}

Bicalho, R. C., V. S. Machado, and L. S. Caixeta. 2009. Lameness in dairy cattle: A debilitating disease or a disease of debilitated cattle? A cross-sectional study of lameness prevalence and thickness of the digital cushion. J. Dairy Sci. 92:3175-3184.

Canadian Council on Animal Care. 1993. Guide to the Care and Use of Experimental Animals. Vol. 1. E. D. Olfert, B. M. Cross, and A. A. McWilliam, ed. CCAC, Ottawa, Ontario, Canada.

Chapinal, N., A. M. de Passillé, D. M. Weary, M. A. G. von Keyserlingk, and J. Rushen. 2009. Using gait score, walking speed, and lying behavior to detect claw horn lesions in dairy cows. J. Dairy Sci. 92:4365-4374

Chapinal, N., D. M. Veira, D. M. Weary, and M. A. G. von Keyserlingk. 2007. Validation of a system for monitoring individual feeding and drinking behavior and intake in group housed cattle. J. Dairy Sci. 90:5732-5736.

Cook, N. B., T. B. Bennett, and K. V. Nordlund. 2004. Environmental influences on claw horn lesions associated with laminitis and sub-acute ruminal acidosis (SARA) in dairy cows. J. Dairy Sci. 87(E-Suppl.):E36-E46.

Cook, N. B., and K. V. Nordlund. 2009. Review: The influence of the environment on dairy cow behavior, claw health and herd health lameness dynamics. Vet. J. 179:360-369.

Devries, T. J., K. A. Beauchemin, and M. A. G. von Keyserlingk. 2007. Dietary forage concentration affects the feed sorting behavior of lactating dairy cows. J. Dairy Sci. 90:5572-5579.

Espejo, L. A., M. I. Endres, and J. A. Salfer. 2006. Prevalence of lameness in high-producing Holstein cows housed in freestall barns in Minnesota. J. Dairy Sci. 89:3052-3058.

Fairfield, A. M., J. C. Plaizier, T. F. Duffield, M. I. Lindinger, R. Bagg, P. Dick, and B. W. McBride. 2007. Effects of prepartum administration of a monensin controlled release capsule on rumen $\mathrm{pH}$, feed intake, and milk production of transition dairy cows. J. Dairy Sci. 90:937-945.

Fregonesi, J. A., M. A. G. von Keyserlingk, C. B. Tucker, D. M. Veira, and D. M. Weary. 2009. Neck-rail position in the freestall affects standing behavior, udder and stall cleanliness. J. Dairy Sci. 92:1979-1985.

Galindo, F., and D. M. Broom. 2000. The relationships between social behavior of dairy cows and the occurrence of lameness in three herds. Res. Vet. Sci. 69:75-79.

Galindo, F., D. M. Broom, and P. G. G. Jackson. 2000. A note on possible link between behavior and the occurrence of lameness in dairy cows. Appl. Anim. Behav. Sci. 67:335-341.

Goldhawk, C., N. Chapinal, D. M. Veira, D. M. Weary, and M. A. G. von Keyserlingk. 2009. Prepartum feeding behavior is an early indicator of subclinical ketosis. J. Dairy Sci. 92:4971-4977.
González, L. A., B. J. Tolkamp, M. P. Coffey, A. Ferret, and I. Kyriazakis. 2008. Changes in feeding behavior as possible indicators for the automatic monitoring of health disorders in dairy cows. J. Dairy Sci. 91:1017-1028.

Greenough, P. R., and J. J. Vermunt. 1991. Evaluation of subclinical laminitis in a dairy herd and observations on associated nutritional and management factors. Vet. Rec. 128:11-17.

Huzzey, J. M., D. M. Veira, D. M. Weary, and M. A. G. von Keyserlingk. 2007. Prepartum behavior and dry matter intake identify dairy cows at risk for metritis. J. Dairy Sci. 90:3220-3233.

Knott, L., J. F. Tarlton, H. Craft, and A. J. Webster. 2007. Effects of housing, parturition and diet change on the biochemistry and biomechanics of the support structures of the hoof of dairy heifers. Vet. J. 174:277-287.

Leach, K. A., D. N. Logue, J. M. Randall, and S. A. Kempson. 1998 Claw lesions in dairy cattle: Methods for assessment of sole and white line lesions. Vet. J. 155:91-102.

Leonard, F. C., J. M. O'Connell, and K. J. O'Farrell. 1994. Effect of different housing conditions on behavior and foot lesions in Friesian heifers. Vet. Rec. 134:490-494.

Lischer, C. J., P. Ossent, M. Raber, and H. Geyer. 2002. Suspensory structures and supporting tissues of the third phalanx of cows and their relevance to the development of typical sole ulcers (Rusterholz ulcers). Vet. Rec. 151:694-698.

Mitlöhner, F. M., J. L. Morrow-Tesch, S. C. Wilson, J. W. Dailey, and J. J. McGlone. 2001. Behavioral sampling techniques for feedlot cattle. J. Anim. Sci. 79:1189-1193.

Nielsen, B. L. 1999. On the interpretation of feeding behavior measures and the use of feeding rate as an indicator of social constraint. Appl. Anim. Behav. Sci. 63:79-91.

Nocek, J. E. 1997. Bovine acidosis: Implications on laminitis. J. Dairy Sci. 80:1005-1028.

O'Driscoll, K., L. Boyle, and A. Hanlon. 2008. A brief note on the validation of a system for recording lying behavior in dairy cows. Appl. Anim. Behav. Sci. 111:195-200.

Proudfoot, K. L., D. M. Veira, D. M. Weary, and M. A. G. von Keyserlingk. 2009. Competition at the feed bunk changes the feeding, standing, and social behavior of transition dairy cows. J. Dairy Sci. 92:3116-3123.

SAS Institute. 2003. SAS Users Guide. Version 9.1. SAS Institute Inc., Cary, NC.

Tarlton, J. F., D. E. Holah, K. M. Evans, S. Jones, G. R. Pearson, and A. J. Webster. 2002. Biomechanical and histopathological changes in the support structures of bovine hooves around the time of first calving. Vet. J. 163:196-204.

Tolkamp, B. J., and I. Kyriazakis. 1999. To split behavior into bouts, log-transform the intervals. Anim. Behav. 57:807-817.

Tucker, C. B., D. M. Weary, and D. Fraser. 2004. Free-stall dimensions: Effects on preference and stall usage. J. Dairy Sci. 87:12081216.

Webster, A. J. F. 2002. Effects of housing practices on the development of foot lesions in dairy heifers in early lactation. Vet. Rec. 151:912 . 